DISTRIBUTION SHEET

\begin{tabular}{|c|c|c|c|c|c|}
\hline \multirow{2}{*}{$\begin{array}{l}\text { To } \\
\text { Distribution }\end{array}$} & \multirow{2}{*}{\multicolumn{3}{|c|}{$\begin{array}{l}\text { From } \\
\text { TWRS Safety Special Projects }\end{array}$}} & \multicolumn{2}{|c|}{ Page 1 of 1} \\
\hline & & & & \multicolumn{2}{|c|}{ Date $12 / 20 / 94$} \\
\hline \multirow{2}{*}{\multicolumn{4}{|c|}{$\begin{array}{l}\text { Project Title/Work Order } \\
\text { Gas Characterization System Functional Design Criteria }\end{array}$}} & \multirow{2}{*}{\multicolumn{2}{|c|}{$\begin{array}{ll}\text { EDT No. } & 600150 \\
\text { ECN No. } & \text { N/A }\end{array}$}} \\
\hline & & & & & \\
\hline Name & MSIN & $\begin{array}{c}\text { Text } \\
\text { With All } \\
\text { Attach. }\end{array}$ & Text Only & $\begin{array}{l}\text { Attach./ } \\
\text { Appendix } \\
\text { Only }\end{array}$ & $\begin{array}{l}\text { EDT/ECN } \\
\text { Only }\end{array}$ \\
\hline $\begin{array}{l}\text { R. E. Bauer } \\
\text { L. S. Krogsrud } \\
\text { J. W. Lentsch } \\
\text { M. L. McElroy } \\
\text { T. C. Schneider } \\
\text { E. K. Straalsund } \\
\text { J. L. Stringer } \\
\text { Central Files }\end{array}$ & $\begin{array}{l}\text { L6-37 } \\
\text { R3-08 } \\
\text { S7-15 } \\
\text { S1-57 } \\
\text { L7-04 } \\
\text { L6-37 } \\
\text { L6-37 } \\
\text { L8-04 }\end{array}$ & $\begin{array}{l}X \\
X \\
X \\
X \\
X \\
X \\
X \\
X\end{array}$ & & & \\
\hline $0 \leq 7 z \quad(2)$ & $28-0$ & $x$ & & & \\
\hline
\end{tabular}




\section{DISCLAIMER}

Portions of this document may be illegible in electronic image products. Images are produced from the best available original document. 


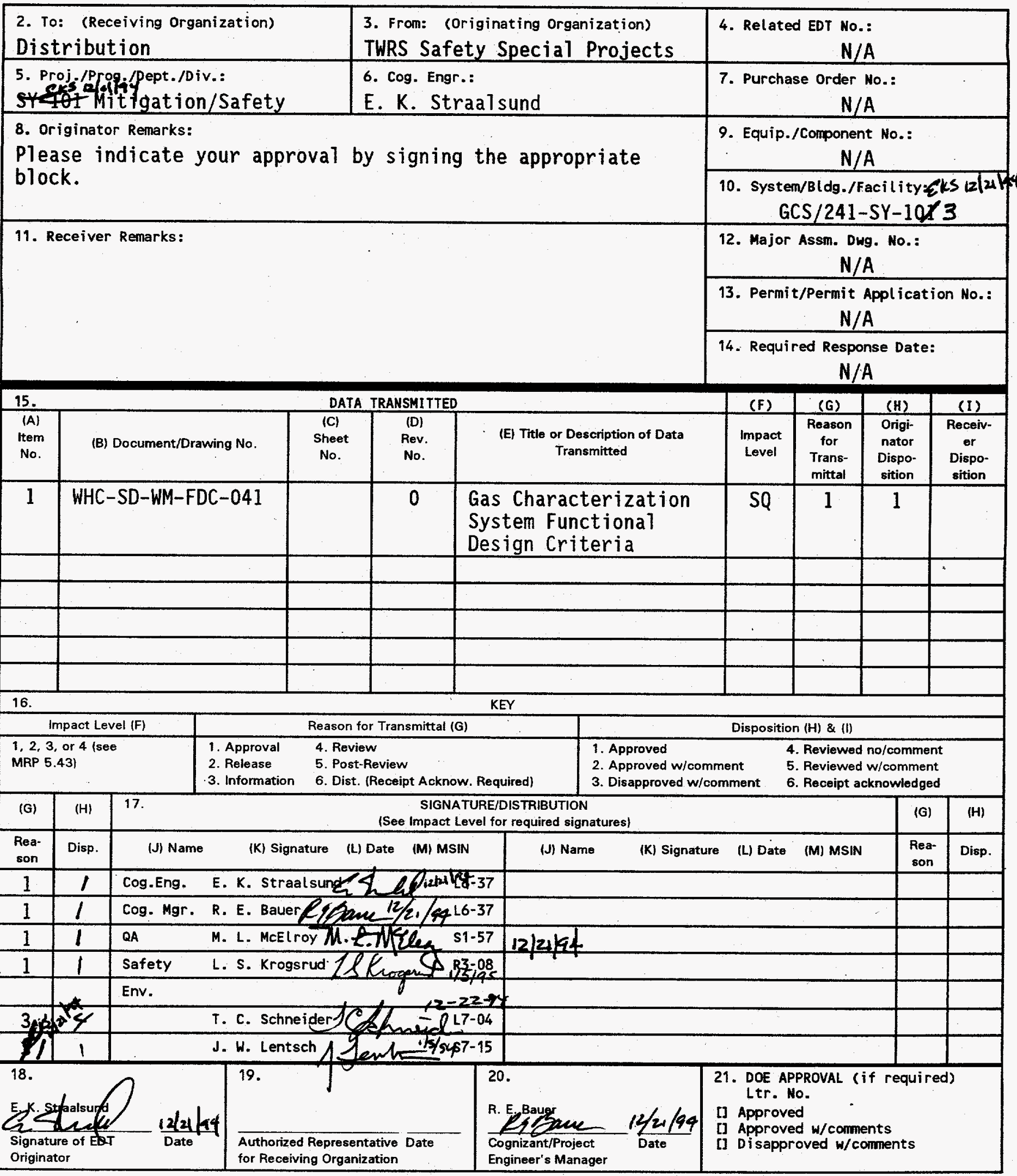




\section{RELEASE AUTHORIZATION}

Document Number: WHC-SD-WM-FDC-041, Revision 0

Document Title: Gas Characterization System Functional Design Criteria

Release Date: $\quad 1 / 5 / 95$

This document was reviewed following the procedures described in WHC-CM-3-4 and is:

\section{APPROVED FOR PUBLIC RELEASE}

WHC Information Release Administration Specialist:

Ghiv 3tilley hom

C. Willingham

$1 / 5 / 95$

TRADEMARK DISCLAIMER. Reference herein to any specific commercial product, process, or service by trade neme, tredenark, mufacturer, or otherwise, does not necessarily constitute or imply its endorsenent, recowinendation, or favoring by the United States Government or any agency thereof or its contractors or subcontrectors.

This report has been reproduced from the best available copy. Available in paper copy and microfiche. Printed in the United States of America. Available to the U.S. Department of Energy and its contractors from:

U.S. Department of Energy

office of Scientific and Technical Information (OSTI)

P.0. Box 62

Dak Ridge, TH 37831

Telephone: (615) 576-8401

Available to the public from:

U.S. Department of Commerce

National Technical Information Service (NTIS)

5285 Port Royal Road

Springfield, VA 22161

Telephone: (703) $487-4650$ 


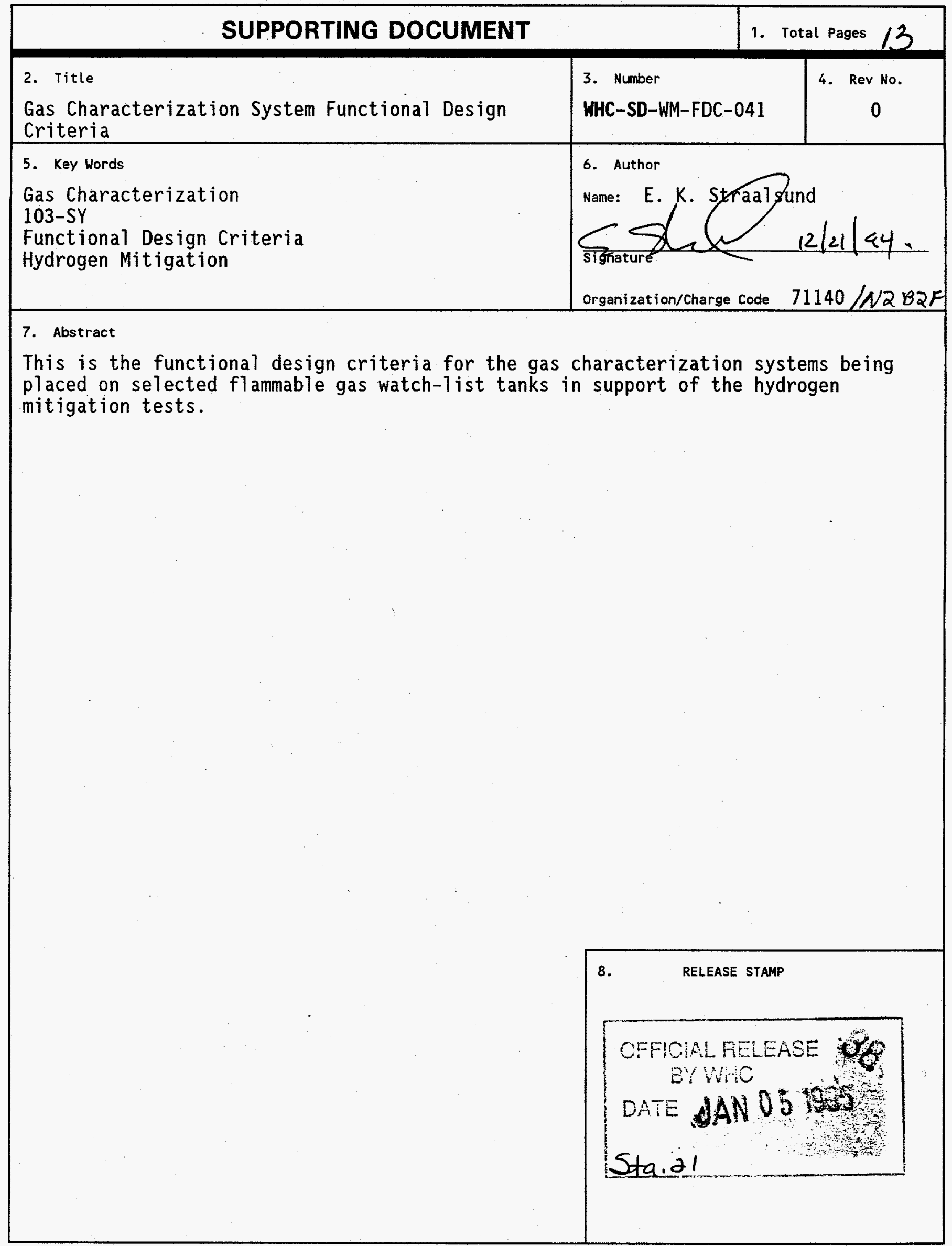




\title{
GAS CHARACTERIZATION SYSTEM FUNCTIONAL DESIGN CRITERIA
}

\author{
December 1994
}

Eric K. Straalsund

TWRS Safety Special Projects

\section{DISCLAIMER}

This report was prepared as an account of work sponsored by an agency of the United States Government. Neither the United States Government nor any agency thereof, nor any of their employees, makes any warranty, express or implied, or assumes any legal liability or responsibility for the accuracy, completeness, or usefulness of any information, apparatus, product, or process disclosed, or represents that its use would not infringe privately owned rights. Reference herein to any specific commercial product, process, or service by trade name, trademark, manufacturer, or otherwise does not necessarily constitute or imply its endorsement, recommendation, or favoring by the United States Government or any agency thereof. The views and opinions of authors expressed herein do not necessarily state or reflect those of the United States Government or any agency thereof.

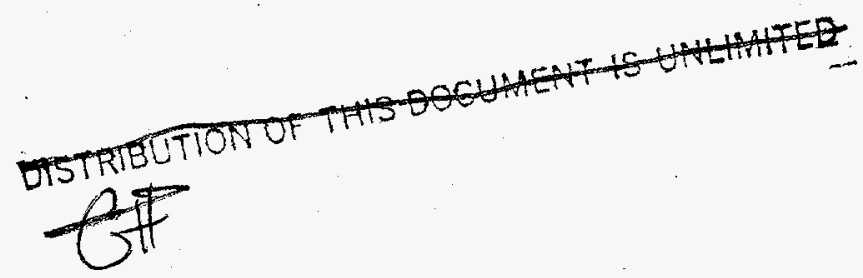


WHC-SD-WM-FDC-041

Revision 0

Page 2

\section{CONTENTS}

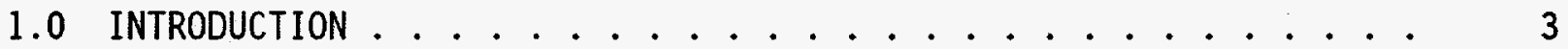

1.1 Background ...................... 3

1.2 Scope ............................... 3

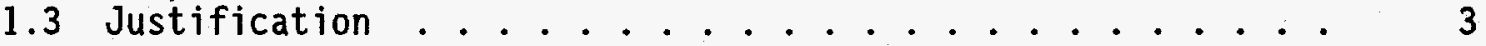

2.0 FUNCTIONAL DESCRIPTION . . . . . . . . . . . . . . . . 4

2.1 System Description . . . . . . . . . . . . . . 4

2.2 Site Location .................. . . 4

3.0 PROCESS DESIGN CRITERIA ................... 5

3.1 Instrumentation and Control ............. 5

3.2 Piping ......................... 7

3.3 General Chemical Process . . . . . . . . . . . . . . 7

3.4 General Mechanical Process . . . . . . . . . . . . 7

3.5 Systems Interface . . . . . . . . . . . . . 8

4.0 FACILITY DESIGN CRITERIA . . . . . . . . . . . . . . 9

4.1 Architectural ...................... 9

4.2 HVAC . . . . . . . . . . . . . . . 9

4.3 Electrical ................. . . . . 9

4.4 Communications and Telecommunications Systems ...... . 9

4.5 Penetrations ... . . . . . . . . . . . . 10

4.6 Compressed Gasses . . . . . . . . . . . . . . . 10

5.0 GENERAL REQUIREMENTS .................... 10

5.1 Safety Class . . . . . . . . . . . . . . . . 10

5.3 Quality Assurance .................. 10

5.4 Operating Personne1 and Services............. 11

6.0 REFERENCES . . . . . . . . . . . . . . . 11 
WHC-SD-WM-FDC-041

Revision 0

Page 3

\section{GAS CHARACTERIZATION SYSTEM FUNCTIONAL DESIGN CRITERIA}

\subsection{INTRODUCTION}

\subsection{Background}

Tank 241-SY-101 (SY-101) is known to experience periodic tank level increases and decreases during which hydrogen gas is released. It is suspected that the generated gases are accumulated in the solids-containing layer near the bottom of the tank. Solids are also present in the surface "crust" Tayer and may be suspended in the liquid layer. The accumulation of gases creates a buoyancy that eventually overcomes the density and cohesive strength of the bottom layer. When this happens, the gas is released upward through the liquid layer and also carries some of the bottom layer upward. Monitoring of Tank SY-10I indicates release concentrations greater than the lower flammability limit (LFL) of hydrogen $\left(\mathrm{H}_{2}\right)$ in a hydrogen/nitrous oxide $\left(\mathrm{N}_{2} \mathrm{O}\right)$ atmosphere.

Other waste tanks have been identified as having the potential to behave similar to SY-101. These tanks have been placed on the flammable gas watch list (FGWL). Al1 tanks on the FGWL wi1l have a standard hydrogen monitoring system installed to measure hydrogen. In the event that hydrogen levels exceed $0.75 \%$ by volume, additional characterization will be required. The purpose of this additional characterization is to determine the actual lower flammability limit of these tanks, accurately measure low baseline gas release concentrations, and to determine potential hazards associated with larger Gas Release Events (GREs).

The vapor monitoring instruments to be installed in the gas characterization facility will allow accurate analys is of the tank vapor. It will be possible to detect a wide range of hydrogen, from parts per million to percent by volume, as well as other gas species suspected to be generated in tanks.

\subsection{Scope}

The scope of this functional design criteria (FDC) document is to define the design criteria specific to a Gas Characterization System (GCS) which can be sited at selected waste tanks.

\subsection{Justification}

Tank SY-101 has one of the highest safety priorities for both the Hanford Site and the U.S. Department of Energy (DOE). However, other waste tanks have been identified as tanks which can potentialiy release 
WHC-SD-WM-FDC-041

Revision 0

Page 4

high level bursts of hydrogen $\left(\mathrm{H}_{2}\right)$. Currently, of the twenty-five (25) watch-1ist tanks, AW-101 and SY-103 have been identified as potentially requiring additional characterization. Analyzing the tank vent gases is required to determine the magnitude and time dependance of the various gases released from these tanks.

\subsection{FUNCTIONAL DESCRIPTION}

\subsection{System Description}

The primary function of the GCS is to provide an environmentally controlled facility to sample the identified waste tank's vapor space gasses and analyze the sampled gasses for hydrogen $\left(\mathrm{H}_{2}\right)$ as well as other suspected gas species which include, but are not limited to methane $\left(\mathrm{CH}_{4}\right)$, nitrous oxide $\left(\mathrm{N}_{2} \mathrm{O}\right)$ and ammonia $\left(\mathrm{NH}_{3}\right)$.

The GCS consists of five major components: the test facility, the sample gas delivery system, the sample gas analytical system, the sample gas grab sample system, and a data system. The test facility shall provide a habitable facility to house scientific equipment for the analys is of the waste tank vapor space gases. The gas monitoring building shall be similar to the unit used for the GMS-2 gas monitoring facility on SY101. The sample gas delivery system shall provide a gas sample to the analytical system. The sample gas analytical system shall be capable of measuring a wide range of hydrogen concentrations and a variety of other suspected gas species, specifically nitrous oxide $\left(\mathrm{N}_{2} \mathrm{O}\right)$, methane $\left(\mathrm{CH}_{4}\right)$ and ammonia $\left(\mathrm{NH}_{3}\right)$, from $1 \mathrm{ppm}$ to $3 \%$ by volume. The grab sample system will provide the capability for independent analys is of the tank gas sample. The data system will store and archive analytical gas monitoring data as well as process variables such as temperature and pressure.

\subsection{Site Location}

The GCS building shall be located so that samples can be drawn from the vapor space or exhaust header at the selected tank. Each site's location shall be selected to minimize the delivery time of the tank gas sample, power availability, and access to data transmission facilities. 


\subsection{PROCESS DESIGN CRITERIA}

\subsection{Instrumentation and Control}

\subsubsection{Instruments, Type, Range, and Accuracy}

The sample gas analytical system shall consist of two dual column gas chromatographs and one FTIR spectrometer with the following measurement ranges and accuracies for a gaseous. mixture consisting primarily of moist air with concentrations of the gasses listed below:

\begin{tabular}{|c|c|c|}
\hline \hline Measured Gas & Range & Accuracy \\
\hline \multirow{3}{*}{$\mathrm{H}_{2}$} & $0-20 \mathrm{ppm}$ & $\pm 3 \mathrm{ppm}$ \\
\cline { 2 - 3 } & $20-30,000 \mathrm{ppm}$ & $\pm 10 \%$ of Reading \\
\hline \multirow{3}{*}{$\mathrm{CH}_{4}$} & $0-100 \mathrm{ppm}$ & $\pm 10 \mathrm{ppm}$ \\
\cline { 2 - 4 } & $100-30,000 \mathrm{ppm}$ & $\pm 10 \%$ of Reading \\
\hline \multirow{3}{*}{$\mathrm{NH}_{3}$} & $1-20 \mathrm{ppm}$ & $\pm 3 \mathrm{ppm}$ \\
\cline { 2 - 4 } & $1-10,000 \mathrm{ppm}$ & $\pm 10 \%$ of Reading \\
\hline \multirow{3}{*}{$\mathrm{N}_{2} \mathrm{O}$} & $1-20 \mathrm{ppm}$ & $\pm 3 \mathrm{ppm}$ \\
\cline { 2 - 4 } & $3-30,000 \mathrm{ppm}$ & $\pm 10 \%$ of Reading \\
\hline
\end{tabular}

Process instrumentation such as flow, pressure, and temperature shall be provided in the ranges and accuracies, are defined in Section 3.3.

The sample gas grab sample system will allow a selected gas sample to be captured and taken to a laboratory for independent analysis.

\subsubsection{Repeatability}

The GCS design shall provide systems for daily validations of the gas analysis instruments with one or more gas species and concentrations.

Engineering process instrumentation shall be able to operate for at least one year between calibrations. 
WHC-SD-WM-FDC-041

Revision 0

Page 6

\subsubsection{Reliability}

Since gas analysis instrumentation is of a complex and sensitive nature its failure will require replacement of the whole instrument with a "hot" spare, "An instrument which has a proven operating performance in a lab environment with lab gasses." Gas analysis instrumentation for the GCS shall be selected for the best performance and MTBF based upon the instrument user data currently available.

The process instrumentation shall have a MTBF of at least 10,000 hours.

\subsubsection{Display Requirements}

The gas analytical systems and selected process instrumentation shall provide a local display of the gas analysis performed and selected process engineering parameters.

\subsubsection{Spare Equipment Requirements}

The gas analysis instrumentation requires a "hot" spare complete instrument when a field instrument fails. Thus, at least one spare GC and FTIR shall be required as "hot" spares to replace field instruments per two (2) GCS facilities installed.

The process instrumentation shall have one spare for each instrument type for up to ten (10) GCS facilities installed.

\subsubsection{Data Storage and Retrieval}

The host processor for the GCS shall provide for storage of the calculated gas concentrations, spectral data-sets, and calibrations for a period of not less than 7 days. This represents 137 Megabytes per day or 960 megabytes per week. Electronic communication means shall also be provided to accommodate accessing and archiving this data without entering the tank farms radiation zones.

Resultant data, defining specific gasses and their concentrations, shall be made electronically available on a file server for access by the LANL, WHC, and PNL review teams. The resultant data sets, placed on a file server, shall comprise nominally 10K bytes per day.

Essential data shall be archived for long term storage (more than one year). 
WHC-SD-WM-FDC-041

Revision 0

Page 7

\subsubsection{Software Design Requirements}

Software systems shall utilize vender supplied software and custom developed interfaces. Custom developed software shall be documentated and validated per WHC-CM-3-10, "Software Practices", Section SP-3.0, "Development" and Section SP-6.0, "Configuration Control"

\subsection{Piping}

3.2.1 The sample stream shall be completely contained within piping or instrumentation between the inlet ports on the tank exhaust header or sample port and release back to the exhaust header or tank vapor space.

3.2.2 Devices that come into contact with the sample stream must be qualified or approved for use in a potentionally flammable environment (Per the definitions in NFPA 70, Article 500, Class I, Division 1, Group B). Nonqualified Apparatus (devices not approved for use in the sample gas stream) must be separated from the sample stream by engineered barriers.

\subsection{General Chemical Process}

The process parameters shall be measured with the following accuracies:

\begin{tabular}{|c|c|}
\hline Measured Parameters & Accuracy \\
\hline \hline Temperatures & $\pm 2{ }^{\circ} \mathrm{C}$ \\
\hline Absolute Pressures & $\pm 1 \%$ of Full Scale \\
\hline Differential Pressures & $\pm 1 \%$ of Full Scale \\
\hline Flow Rates & $\pm 10 \%$ of Full Scale \\
\hline
\end{tabular}

\subsection{General Mechanical Process}

The sample gas delivery system shall meet the following requirements:

3.4.1 Provide the ability to draw a tank gas sample under pressures between -12 and +60 inches of water and be able to structurally withstand temperatures between $-10^{\circ} \mathrm{C}$ and $100^{\circ} \mathrm{C}$ and condensed vapors considered to have a $\mathrm{pH}$ between 8 and 12 . 
WHC-SD-WM-FDC-041

Revision 0

Page \&

\subsubsection{Software Design Requirements}

Software systems shall utilize vender supplied software and custom developed interfaces. Custom developed software shall be documentated and validated per WHC-CM-3-10, "Software Practices", Section SP-3.0, "Development" and Section SP-6.0, "Configuration Control"

\subsection{Piping}

3.2.1 Per the definitions in NFPA 70, Article 500, the sample stream is a Class I, Division 1, Group B environment. Devices that come in contact with the sample stream must be intrinsically safe. Nonqualified Apparatus (devices not approved for use in the sample gas stream) must be separated from the sample stream by engineered barriers.

3.2.2 The sample stream shall be completely contained within piping or instrumentation between the inlet ports on the tank exhaust header or sample port and release back to the exhaust header or tank vapor space.

\subsection{General Chemical Process}

The process parameters shall be measured with the following accuracies:

\begin{tabular}{|c|c|}
\hline Measured Parameters & Accuracy \\
\hline Temperatures & $\pm 2{ }^{\circ} \mathrm{C}$ \\
\hline Absolute Pressures & $\pm 1 \%$ of Full Scale \\
\hline Differential Pressures & $\pm 1 \%$ of Full Scale \\
\hline Flow Rates & $\pm 10 \%$ of Full Scale \\
\hline
\end{tabular}

\subsection{General Mechanical Process}

The sample gas delivery system shall meet the following requirements:

3.4.1 Provide the ability to draw a tank gas sample under pressures between -12 and +60 inches of water and be able to structurally withstand temperatures between $-10^{\circ} \mathrm{C}$ and $100^{\circ} \mathrm{C}$ and condensed vapors considered to have a $\mathrm{pH}$ between 8 and 12 . 
3.4.2 Provide the sampled gas from the sample point to the analytical instruments in less than five minutes and maintain sample delivery speed upon isolation of any analytical instrument.

3.4.3 Provide two submicron sample gas inlet filters inside the GCS building with differential pressure indication.

3.4.4 Provide capability to isolate individual sample line components, as practical, for maintenance.

3.4.5 Provide the necessary fittings filters, valves, piping, and sample containers to allow gas samples to be captured and transported to a laboratory for independent analys is.

3.4.6 Manual sample gas flow control, with local flow and pressure indication, shall be provided.

3.4.7 Exterior sample gas lines shall be trace heated to maintain a minimum sample temperature of $30^{\circ} \mathrm{C}$ to avoid condensate buildup.

3.4.8 Manual sample isolation valves shall be located as close to the tank sample and return points as possible.

3.4.9 Manual isolation valves shall be located in the sample system in such a way to minimize large volumes of trapped gas that would dilute the analyzed sample or calibration gases.

3.4.10 Layout the space in the GCS building to allow expansion for other systems.

3.4.11 The sample shall not be allowed to vent unfiltered to the environment.

\subsection{Systems Interface}

The process instrumentation monitoring pressure, temperature, and flow shall interface to the stand-alone data system via 4-20 mA current 1oops or discrete contact closures. The analytical instrumentation shall have the potential to utilize digital data links to transmit their processed data to future data acquisition systems, such as DACS for display and recording. 


\subsection{FACILITY DESIGN CRITERIA}

\subsection{Architectural}

The design of the GCS building shall meet the requirements for Safety Class 3 structures as specified in SDC 4.1 . As such, it shall be designed to maintain the analytical equipment in a clean, dry and mechanically stable environment when the following external conditions exist:

- air temperature of -23 to $+38^{\circ} \mathrm{C}$

- relative humidity of 5 to $100 \%$ condensing

- $\quad$ wind speeds up to 70 miles/hour

- rain, snow, sleet, lightning, hail, blowing sand and dust

- radiation up to $100 \mathrm{mR} /$ hour

\subsection{HVAC}

The HVAC system must be able to maintain the interior of the GCS building at $24 \pm 3^{\circ} \mathrm{C}$ with all penetrations sealed. Room ambient temperature shall be displayed on a local digital readout that shall provide a 4-20 mA signal to the data system for remote monitoring.

\subsection{Electrical}

4.3.1 AC power to the computers and process instruments shal1 be conditioned to reduce voltage surges and electrical noise.

4.3.2 An uninterruptible power supply (UPS) shall be used to provide power to selected instruments and the system computers.

4.3.3 Outside lighting shall be provided at the personnel access door, and inside lighting shall be provided at a level sufficient for personnel to perform setup and maintenance functions.

\subsection{Communications and Telecommunications Systems}

4.4.1 The GCS building shall be provided with a LAN drop and telephone service. 


\subsection{Penetrations}

4.5.1 Personnel access shall be by a single door which will be gasketed sufficiently to maintain air and dust inleakage near zero.

4.5.2 Penetrations for electrical power, instruments signals, communications, and instrument gasses shall be through conduits sealed to prevent entry of outside air, dust, and vermin.

\subsection{Compressed Gasses}

4.6.1 An outside bottle rack and manifolds shall be provided for several compressed gasses which will be used for GC carrier gas, instrument calibration, and valve actuation.

\subsection{GENERAL REQUIREMENTS}

\section{$\underline{5.1}$ Safety Class}

The GCS has been classified as a Safety Class 3 system in accordance with the requirements of WHC-CM-1-3, "Management Requirements and Procedures," MRP-5.46, "Safety Classification of Systems, Components and Structures," since its failure could adversely effect the health and safety of the operating personnel inside the GCS building. Failure of the system could also result in a release of radioactive material to the environment. General design and quality assurance requirements for Safety Class 3 items shall be followed.

\section{$\underline{5.2}$ Fire protection}

Fire Protection or suppression will not be required for the GCS Facility per DOE Order 5480.7A, Fire Protection. Since the facility will not normally be occupied by personnel, contains a dollar amount of equipment under the minimum limit, and its loss will not be a serious threat to personnel safety or the environment.

\subsection{Quality Assurance}

Documentation associated with the design and construction of the GCS shall be assigned Approval Designator SQ for purposes of document approval. This is based on the requirements of WHC-CM-3-5, Section 
WHC-SD-WM-FDC-041

Revision 0

Page 12

12.7, Rev. 0, Approval of Environmental, Safety, and Quality Affecting Documents.

\subsection{Operating Personnel and Services}

The GCS shall be designed such that the building shall not normally need to be staffed by operating personnel.

\subsection{REFERENCES}

6.1 HPSDCM, Hanford Plant Standards Design Criteria, SDC 4.1, Rev. 11, Standard Arch-Civil Design Criteria Design Loads for Facilities.

6.2 WHC-CM-1-3, Management Requirements and Procedures, MRP-5.46, Safety Classification of Systems, Components and Structures.

6.3WHC-CM-3-5, Document Control and Records Management Manual, Section 12.7, Rev. 0, Approval of Environmental, Safety, and Quality Affecting Documents.

6.4 DOE Order, 5480.7A, Fire Protection. 